\title{
Karl Polanyi and the Global Network Inspired by His Work
}

\author{
Marguerite Mendell interviewed by Brigitte Aulenbacher and \\ Andreas Novy
}

\author{
Marguerite Mendell $\cdot$ Brigitte Aulenbacher $\cdot$ Andreas Novy
}

(C) The Author(s) 2019

\section{Introduction}

Marguerite Mendell is the Director of the Karl Polanyi Institute of Political Economy Montreal. Many awards show the extraordinary relevance of her work: Member, Order of Canada; Officer, Order of Québec; laureate Prix Québec, Marie-Andrée Bertrand and Prix ACFAS, Pierre Dansereaux. She is one of the most prominent protagonists of research and discussions about the problems of "our time" (Polanyi) referring to Karl Polanyi's work. Furthermore, it has been not the least her engagement in building up the Karl Polanyi archive which enables us to get insights in his work and biography. For so many institutions and persons Marguerite Mendell is the first address to get in touch with the worldwide Karl Polanyi community, a pluralistic, open minded network giving space for many initiatives of established and young scholars and people from civil society interested in developing perspectives for a better world by putting economy in its place instead of the market driven "demolition of society" (Polanyi). Besides Marguerite Mendell's work on the legacy of Karl Polanyi and in the global Polanyi community, her own research agenda is not less impressive in the field of the social and solidarity economy. On the occasion

M. Mendell

Karl Polanyi Institute of Political Economy, Concordia University, 1455 Blvd. de Maisonneuve, H3G 1M8 Montreal, Quebec, Canada

E-Mail: marguerite.mendell@concordia.ca

B. Aulenbacher $(\square)$

Institute of Sociology, Dept. for the Theory of Society and Social Analyses, Johannes Kepler University, Altenberger Str. 69, 4040 Linz, Austria

E-Mail: brigitte.aulenbacher@jku.at

A. Novy

Institute for Multi-Level Governance and Development, WU Wien,

Welthandelsplatz 1/D4, 1020 Vienna, Austria

E-Mail: andreas.novy@wu.ac.at 
of the foundation of the International Karl Polanyi Society Vienna on 8 May 2018 we invited her to give this interview which allows us to get a lot of insights in her impressive work.

\section{Interview}

Brigitte Aulenbacher and Andreas Novy As director of the Karl Polanyi Institute of Political Economy you are heading the core institution of the worldwide scientific community referring to his œuvre. Could you please give us some insights into the history of the institute and the major tasks it fulfills concerning the legacy of Karl Polanyi?

Marguerite Mendell I co-founded the Karl Polanyi Institute of Political Economy with Kari Polanyi Levitt, Polanyi's daughter and Professor Emerita, McGill University, in 1988. My own discovery of Karl Polanyi was in the late 1970's in my research for my doctoral dissertation, which I completed in the early 1980's. As a graduate student in Economics, I was surprised that we had never been exposed to Polanyi's writings. At the time, History of Economic Thought and Economic History were part of the graduate curriculum, yet his writings were not on any syllabus, in hindsight, this is not a surprise, given that Polanyi's influence was almost exclusively in Economic Anthropology at the time and interdisciplinary dialogue was rare. Fortunately, I had an excellent thesis supervisor who was equally inspired by this discovery. This was the beginning of an intellectual journey into the life and work of Karl Polanyi that has guided my research and led to my collaboration with Kari Polanyi Levitt over the last three decades.

We celebrated the 30th anniversary of the Institute this year. In 1986, the Hungarian Academy of Sciences hosted an international Karl Polanyi conference, commemorating the centenary of his birth. Professor Polanyi-Levitt and I travelled to Budapest and participated in the discussions leading up to this conference, proposing speakers and themes to complement the program planned by our Hungarian colleagues. We co-edited a collection of Polanyi writings, translated into Hungarian and published by Gondolat Press for this occasion. ${ }^{1}$ It was the first large international gathering of Polanyi scholars, representing all disciplines across the social sciences and humanities. Lively discussions and debates continued over several days during the conference and in informal settings. The desire to continue the conversation begun in Budapest led to plans for a second international conference, to be held in Montreal in 1988.

There were important confluences leading up to the Budapest conference. Thanks to a post-doctoral fellowship awarded by the Social Sciences and Humanities Re-

\footnotetext{
1 Our introductory essay was also published in English. Kari Polanyi-Levitt and Marguerite Mendell. 1987. Karl Polanyi: His Life and Times. Studies in Political Economy 22(1):7-39. An abridged version of this article appeared in Telos the same year: Karl Polanyi: A Biographical Sketch. Telos 1987:121-131. As access to the Polanyi archive was not yet available, this essay was an important contribution to the intellectual biography of Karl Polanyi at the time.
} 
search Council, Canada, I was able to accept the invitation by Kari Polanyi Levitt to work with her on her father's archive. Over 50 boxes of archival material required sorting and cataloguing beyond the preliminary work already completed by Ilona Ducyznska, Karl Polanyi's wife and Kari Polanyi Levitt's mother. I was honored to work on this extraordinary project and began a journey into the life and work of Karl Polanyi. My Hungarian and Kari Polanyi Levitt's German, led to fascinating exchanges about what we were discovering in addition to the extensive English material. I was hosted by Concordia University's interdisciplinary PhD in Humanities as a Post-Doctoral Fellow, prior to becoming a member of Concordia's Faculty. The university welcomed the archive project and plans to host the second international conference and proposed that we consider establishing a Karl Polanyi Institute to create a permanent space for discussion, debate, research, inspired by the work of Polanyi. We received this invitation with enthusiasm and formally launched the Polanyi Institute at Concordia University in Montreal in the fall of 1988. Several participants of the Budapest conference were invited to join the Board of Advisors which was expanded over time to include additional Polanyi scholars.

We have organized biennial conferences since 1988, alternating in Montreal and other host cities, reflecting the commitment of the Institute to an international conversation, not bound by the location of the Institute in Montreal. Indeed, the internet has greatly increased our capacity to achieve this objective. We published several edited volumes of selected papers presented at Polanyi conferences. With the availability of the internet, we now include all conference papers on the Institute web site. The Institute also collaborates with other academic networks increasingly interested in organizing Polanyi conferences, workshops, and seminars. These activities have grown over the years, reflecting the increasing influence of Polanyi across disciplines.

Our objective was also to provide full access to the Polanyi archive to students, faculty and public intellectuals interested in and inspired by the work of Karl Polanyi. We have welcomed visiting researchers, for short periods of time, or for longer residencies. Several have returned numerous times. Our wish was to make the archive available in a setting that invites conversation, discussion, meetings between people, in contrast to a library setting. I believe our greatest achievement has been the digitalization of the entire collection, giving the widest possible access to the entire Polanyi œuvre.

Brigitte Aulenbacher and Andreas Novy Over the last years, Karl Polanyi's œuvre has inspired discussions all around the globe. There are many scientific centers and communities performing research, but also using Polanyian concepts and analyses to answer a wide range of questions on contemporary capitalisms. What do you identify as core issues? Which research areas are covered by the international Polanyi community? How does the Karl Polanyi Institute of Political Economy collaborate within these scientific communities?

Marguerite Mendell Indeed, Polanyi's œuvre continues to inspire discussions around the world in universities, research centers, and scholarly communities. When the Institute was established, the work of Polanyi was well known in economic 
history and economic anthropology. His writings created a school which rivalled dominant thinking in economic anthropology in the 1960's. Formalists applied neoclassical theory unreservedly to all societies, regardless of institutional, historical and cultural contexts while substantivists followed Polanyi's lead in situating economies within these contexts, breaking with neo-classical theory. New economic sociology has been influenced by Polanyi, since the early 1980's, with its focus on embeddedness. His influence in economic theory has been scant to say the least, despite his seminal article on Carl Menger that appeared in an edited collection in anthropology, thus not challenging economic orthodoxy from within. His participation in the socialist accountancy debates with Ludwig von Mises went largely unnoticed by economists and came to light in our archival work, now available in translations from German into French and English. Socio-economics drew upon Polanyi but remained marginal to the discipline. Today, Polanyi is identified with heterodox economics. The current interest in the work of Polanyi is reviving political economy, taking us beyond those disciplines that have been open to inter-disciplinarity. This is his greatest contribution to scholarship in the 21 st century, often referred to as Polanyi's century.

The surge of current interest in Polanyi, however, begins with the collapse of Communism in 1989, peaking again with Seattle in 1999 and growing even more rapidly since the 2008-2009 financial crisis. The core issues common to all who are influenced by Polanyi is the resonance of his critique of the self-regulating market economy with social, political, economic and environmental crises today. Polanyi's documentation of the installation of the free market in The Great Transformation, complete with regulatory limits and restrictive legislation, resonates with similar processes under way since the 1970's. "Liberalism was planned; planning was not" summarizes the history of the last four decades of continuous state intervention to maintain capitalism and to contain its tendency to crisis, under the guise of the free market. The consequences of these four decades of planned neoliberalism on all aspects of life, runs through the work of Polanyi scholars today.

There is another important strand in Polanyi's œuvre and that is, agency. Scholars interested in the role of social movements, of counter movements to neoliberalism, in the north and in the south, however fragmented and scattered they may be, turn to the work of Polanyi, in particular, to his writings in Vienna and in the UK in the 1920s and 1930s and to documents discovered in the archive during those years. The Vienna writings, for example, prefigure the actions of civil society initiatives today, even if the times and the forms these take, differ. What is common to both periods and is at the heart of these writings by Polanyi, is his belief in the capacity of people, of communities to take hold of their lives, to "re-embed the economy in society", in the values, needs and desires of communities, regions, across the globe. In my own work, I have referred to these initiatives and their diversity as processes of economic democratization.

These two dominant strands of interest in Polanyi by scholars today in all disciplines converge, of course. The latter has grown considerably since 1989; the former has dominated the interest in the work of Polanyi. And there is the ongoing interest in Polanyi within the fields of economic anthropology and economic history, in the history of the times in which he lived and in his biography. 
There are several important new publications about Polanyi providing greater insight into his life and work. Over the last two years, a $\mathrm{PhD}$ student has been working on an Institute project, "Insights into the Reception of the Work of Karl Polanyi 2000-2018", documenting the influence of Polanyi since the year 2000 across disciplinary boundaries. We hope to produce the results of this important bibliographic research in $2019 .^{2}$

We collaborate with Polanyi scholars internationally and welcome the establishment of new networks, research centers and institutes, most recently the International Karl Polanyi Society in Vienna. Our collaboration takes various forms, including co-hosting conferences. For example, the most recent International Karl Polanyi Conference in Seoul was co-hosted with the Karl Polanyi Institute Asia, located in Seoul. We collaborated in the creation of this Institute, the first in Asia.

Brigitte Aulenbacher and Andreas Novy Since the 1990s and enforced by the financial crisis 2008 we have witnessed a kind of "Polanyi-hype" in many fields of research. From your perspective, why does his œuvre fascinate so many scholars coming from different disciplines and focusing on diverse topics?

Marguerite Mendell The current "Polanyi-hype" is no surprise. We are not only facing very difficult and troubling times, but there is also a theoretical vacuum. That search continues and many are re-reading Marx and Keynes, for example, or the utopian socialists or turning, for example, to new areas in social science, borrowing from complexity theory or design theory, for direction. The "hype", reflects the contemporary resonance of Polanyi's analysis of social dislocation, of the devastation on the lives of men and women subject to the edicts of the market economy. As well, the numerous regulations and ad hoc crisis management that continue to prop up a failing system, are testimony to Polanyi's argument that the self-regulating market is a utopia, a fiction. Today, it is the rhetoric of the free market that dominates, not the free market itself.

The predictions of the impact on society of the 4th industrial revolution-artificial intelligence, the digital economy, the absence of any regulatory framework to contain the rapid commodification of digital space and its capture by private capital, of the emerging gig economy and the employment crisis as skills, jobs and work itself in many cases, disappear, increases the Polanyi "hype" today. At the same time, the numerous counter-movements around the world reclaiming and democratizing the economy, whether at the level of the enterprise and the growth of the social and solidarity economy and forms of collective ownership including within digital space, or at the level of community or municipalities transforming local economies, including the commons, contribute to Polanyi hype as well. How society does or does not respond to market forces and the commodification of life, is at the source of this Polanyi "hype".

\footnotetext{
2 This project is funded by the School of Graduate Studies, Concordia University. Kristopher Millet is compiling this annotated bibliography that will be available online. Concordia University Libraries has provided invaluable guidance by suggesting software for this work which will permit on line discussion.
} 
Brigitte Aulenbacher and Andreas Novy Concerning your own research agenda: What are the most impressive motives, concepts and terms in Polanyi's œuvre and how do you read them in investigating contemporary transformations?

Marguerite Mendell My own work over the last few decades has been on processes of economic democratization and how these processes are institutionalized in different contexts. Polanyi's writings in Vienna in the 1920s and 30s have been an important source of inspiration for me. While the political environment of Vienna in the 1920s provided fertile ground upon which to construct a framework for economic democracy, what transcends the specificity of this period is Polanyi's insistence on agency, on the role of movements (the labour movement in Vienna at the time), on the capacity of citizens to co-design new institutional arrangements embedded in processes of democratic deliberation. I am reversing the term deliberative democracy to move beyond political deliberation to Polanyi's framework of political economy, of societal organization. His later work on education in the U.K. emphasizes the need for empowerment where agency has been weakened, this time by empowering working men and women with educational content and tools that reflect their lived realities. These writings drill down, so to speak, to underlying conditions of transformation, so often submerged in macro analysis of crisis and at the heart of systemic change.

Brigitte Aulenbacher and Andreas Novy And more in general, what do we have to consider if we make use of an approach developed in the period between WW I and II. What was context-specific and unique? What are the similarities? What are the differences?

Marguerite Mendell What I have not raised thus far, is the looming dark shadow of fascism of the inter-war period with right wing populism as a very powerful counter-movement to neoliberalism today, contesting progressive citizen based counter-movements to neo-liberalism. The "Essence of Fascism" and several articles written by Polanyi in the UK in the 1930s, pit democracy and fascism as a choice between a society dominated by the market or a socialist society dominated by values of democracy. The large numbers of working people in regions and countries around the world, drawn to the populist right, recalls the rise of fascism in the interwar period. Today, migration and the refugee crisis, especially in Europe, a shifting geopolitical world order, have increased popular support for authoritarian parties. Polanyi's writings were prescient during his time and even more so today. Market ideology has betrayed working people everywhere, not the least of which is in those countries where hope for a better life after the fall of Communism quickly transformed into despair and ultimately into resentment and a turn to the right, paving the way for authoritarian regimes. The same is true elsewhere, not the least of which is Trump's America built on resentment of a powerful internationalist liberal elite and its perceived betrayal of working people.

Brigitte Aulenbacher and Andreas Novy There has been a growing work about Polanyi's biography, his œuvre and its relevance for the analysis of contemporary 
developments. Which desiderates would you identify? Which are your next projects? What does the Karl Polanyi Institute of Political Economy plan to do in the next years?

Marguerite Mendell I mentioned the growing interest in Polanyi's work including biographical research. Recent books and articles give great insight into his life, his intellectual formation and influences, the times in which he lived, his participation in political life, and so on. These writings have brought scholars to the Institute over the years and for the most part, they have spent a great deal of time researching the Archive, interviewing various Polanyi scholars and some of his very close former students and family. The last of his well-known students, Abraham Rotstein, died a few years ago. Kari Polanyi Levitt continues to generously meet with researchers interested in her father's life and work and has contributed significantly to knowledge about him and the contexts, in which he lived, in Europe, in the U.K., in the United States and in Canada, where he died in 1964. Her own writings on Polanyi are invaluable sources for Polanyi scholars.

The Institute is the repository of the Karl Polanyi Archive. We are very proud to have completed our project to digitalize the entire collection, which is now easily available on the web. Recently, Kari Polanyi Levitt donated the original Polanyi archive to the Concordia University Library. We continue to update the Archive, add new material as it becomes available (additions to the archive have been made continuously all these years) and we hope that the current bibliographic project documenting influences of Polanyi on scholarship across disciplines, will continue, subject to funding. This is extremely important and useful to the scholarly community as it reveals the impact of Polanyi on theoretical and applied research in all fields, with larger epistemological implications. The results of this project will be on line with interactive capability to encourage dialogue and debate. We will continue to welcome and receive researchers to the Institute, as we have these last 30 years. And we will host and co-host international conferences, alternating between Montreal and abroad. The Institute also organizes seminars, public lectures, and workshops. This last year has been particularly active.

Brigitte Aulenbacher and Andreas Novy Karl Polanyi has been a scientist, journalist and public intellectual. How would you describe his legacy concerning the relation between science and publics? How does the scientific community refer to his work? And what is necessary so that his work and the work he has inspired can address wider publics?

Marguerite Mendell While the interest in Polanyi is largely within the academic community, there are numerous individuals and organizations that are aware of and inspired by his work and influence. And there are public intellectuals who make his work available through articles in on-line and print magazines, and news media, radio and film documentaries. As well, the numerous engaged Polanyi scholars who collaborate with civil society organizations and actors, take the work of Polanyi outside academia into the wider public. This is certainly true for the large number of scholars working with social movements, the social and solidarity economy, citizen 
based initiatives, and so on. We work collaboratively with these publics who are our research partners and with whom we share the influence of Polanyi through analysis and action.

Brigitte Aulenbacher and Andreas Novy There are many centers, communities and societies-like the recently founded International Karl Polanyi Society in Vienna. Is there a division of labor between these institutions? How has collaboration been organized so far? What would be most important to improve the worldwide Polanyi-inspired dialogue on understanding and shaping the ongoing transformations?

Marguerite Mendell Yes, the number of centers, networks, communities and societies are growing and this is very good. The International Karl Polanyi Society in Vienna is the most recent, preceded by the Karl Polanyi Institute Asia that is bringing Polanyi scholars in Asia together. There is no strict division of labour between them, nor should there be. Each is both independent and collaborative. The forms of collaboration with the Polanyi Institute vary, including joint organization of conferences, workshops, etc., exchanges between researchers and graduate students and most important, the development of joint research projects, when possible. And there is ongoing communication between them. These conversations, whatever form they take, must continue and be nurtured. We invite joint publications, webinars, and hyperlinks on our individual web sites, and so on. I mention webinars but we have not organized these as yet. This could be a way to link our various communities by inviting members to host a webinar, available to all. These could be held a few times each year. The collaboration, solidarity and sharing thus far have been excellent but often, on an ad hoc basis. Perhaps now is the time to institutionalize certain forms of collaboration.

Funding Open access funding provided by Johannes Kepler University Linz.

Open Access This article is distributed under the terms of the Creative Commons Attribution 4.0 International License (http://creativecommons.org/licenses/by/4.0/), which permits unrestricted use, distribution, and reproduction in any medium, provided you give appropriate credit to the original author(s) and the source, provide a link to the Creative Commons license, and indicate if changes were made.

Marguerite Mendell is Professor Emerita at the Concordia University and Director of the Karl Polanyi Institute of Political Economy, Montreal. Author and editor of numerous books and articles including: Commoning and the Commons-Alternatives to a Market Society. In Karl Polanyi's Vision of Socialist Transformation, eds. Michael Brie and Claus Thomasberger. Montreal, Black Rose Books, 2018; Democratizing Capital: Social and Solidarity Finance in Quebec. In Social Economy in China and the World, eds. Ngai Pun, Ben Hok-bun Ku, Hairong Yan, and Anita Koo. London, Routledge, 2015; Karl Polanyi and the Instituted Process of Economic Democratisation. In Karl Polanyi. New perspectives on the place of the economy in society, M. Harvey, M. Ramlogan, and S. Randles. Manchester: Manchester University Press, 2007. Research interests: Economic Democracy, Social and Solidarity Economy, the City as Commons (in all cases the important influence of Karl Polanyi). 
Brigitte Aulenbacher is professor of sociological theory and social analysis, heads the Department for the Theory of Society and Social Analyses at the Institute of Sociology at the Johannes Kepler University Linz/ Austria, co-chairs (with Helma Lutz and Karin Schwiter) the project "Decent care work? Transnational home care arrangements", co-edits (with Klaus Dörre) Global Dialogue- the Magazine of the International Sociological Association ISA and is the vice-president of the International Karl Polanyi Society. Recent international publications are: Global sociology of care and care work, Current Sociology Monograph, Vol. 2, No. 4, Monograph 2, Sage 2018 (edited together with H. Lutz and B. Riegraf); Care and care work-a question of economy, justice and democracy, special issue of Equality, Diversity and Inclusion, Vol. 37, No. 4, Emerald Publishing 2018 (edited together with B. Riegraf); Leistung und Gerechtigkeit. Das umstrittene Versprechen des Kapitalismus (edited together with M. Dammayr, K. Dörre, W. Menz, B. Riegraf, H. Wolf), Beltz Juventa 2017.

Andreas Novy is the president of the International Karl Polanyi Society, hosted at the Institute for MultiLevel Governance and Development (MLGD) at Vienna University of Economics and Business. He is a socioeconomist, associate professor at and head of MLGD. He has published extensively in the field of urban development, social innovation, development studies and transdisciplinarity. He has been head of the Austrian Green Foundation, co-founder of the Viennese Paulo Freire Center and co-organizer of two Good Life for all-Congresses in Vienna. Most recent publications include the editing (together with C. Thomasberger und M. Brie) of Kari Polanyi: Die Finanzialisierung der Welt. Karl Polanyi und die neoliberale Transformation der Weltwirtschaft (forthcoming-2019, Beltz Juventa) and Local social innovation to combat poverty and exclusion: a critical appraisal, together with S. Oosterlynck and Y. Kazepov (forthcoming2019, Polity Press). 